$\begin{array}{ll} & \text { Etnográfica } \\ \text { etnográfica } & \text { Revista do Centro em Rede de Investigação em }\end{array}$

Antropologia

vol. 20 (3) | 2016

Vol. 20 (3)

\title{
O verbo e o gesto: corporeidade e performance nas folias de reis
}

The word and gesture: embodiment and performance in folias de reis

\section{Gilmar Rocha}

\section{(2) OpenEdition \\ Journals}

\section{Edição electrónica}

URL: https://journals.openedition.org/etnografica/4658

DOI: 10.4000/etnografica.4658

ISSN: 2182-2891

\section{Editora}

Centro em Rede de Investigação em Antropologia

\section{Edição impressa}

Data de publição: 1 outubro 2016

Paginação: 539-564

ISSN: 0873-6561

\section{Refêrencia eletrónica}

Gilmar Rocha, «O verbo e o gesto: corporeidade e performance nas folias de reis», Etnográfica [Online], vol. 20 (3) | 2016, posto online no dia 27 novembro 2016, consultado o 11 fevereiro 2022. URL: http:// journals.openedition.org/etnografica/4658 ; DOI: https://doi.org/10.4000/etnografica.4658

\section{(c) (1) (8)}

Etnográfica is licensed under a Creative Commons Attribution-NonCommercial 4.0 International License. 


\section{O verbo e o gesto: corporeidade e performance nas folias de reis}

\section{Gilmar Rocha}

Folias de reis são manifestações de religiosidade popular de grande importância em algumas localidades do Brasil. Durante o ciclo natalino as folias saem em peregrinação nas áreas urbanas e rurais levando a palavra sagrada aos devotos dos Santos Reis; em troca recebem doações, comida e pousada, colocando em circulação o sistema da dádiva. Não por acaso, a compreensão desses grupos precatórios encontra na obra de Marcel Mauss (1872-1950) uma fonte de análise inspiradora. Em especial o corpo, em sua dimensão performativa, gestual, emocional, ocupa uma centralidade simbólica nas folias, nos deixando ver um complexo sistema de "gestos elementares da reciprocidade". A análise se desenvolve com base em etnografia realizada junto à folia Estrela Guia, em suas jornadas na região de Vassouras (RJ), nos anos de 2012 e 2013.

PALAVRAS-CHAVE: dádiva, corpo, gestos, emoção, folia de reis.

The word and gesture: embodiment and performance in folias de reis . Folias de reis are popular religious manifestations which have great importance in some regions of Brazil. During the Christmas cycle, folias' pilgrims start their journey in urban and rural areas conveying the sacred word to devotees of the Holy Kings; in return they receive donations, food and lodging, thus putting into movement the donation system. Not coincidentally, the understanding of these groups finds in the work of Marcel Mauss (1872-1950) a source of inspirational analysis. In particular, the body, in its performative, gestural, and emotional dimensions, occupies a symbolic centrality in folias, revealing a complex system of "elementary gestures of reciprocity". The analysis is developed based on ethnography elaborated among a folia known as Estrela Guia, in its pilgrimage through the city of Vassouras (RJ), in the years 2012 and 2013.

KEYWORDS: gift, body, gesture, emotion, folia de reis.

ROCHA, Gilmar (gr@id.uff.br) - Universidade Federal Fluminense (UFF), Brasil. 
“... 'sem a iniciativa de um gesto gracioso', para usarmos as palavras de Aristóteles, nada pode existir" (Godbout 1999: 157).

\section{O CORPO FALA}

A folia chegou em visita à casa do "Seu Lelo", no bairro da Granja, na distante Paty do Alferes (RJ), aproximadamente a 80 quilómetros da cidade de Vassouras (RJ), por volta das $14 \mathrm{~h} .{ }^{1}$ A casa, localizada no final da rua, de cor azul-claro, parecia ser a continuação do céu na terra, tal era a luminosidade do dia. O presépio estava montado na entrada da casa, local no qual se misturavam os espaços da varanda com o da garagem. A lateral coberta com uma proteção plástica transparente impedia a circulação do ar e evitava a entrada da poeira da rua ainda sem pavimentação. Aquela "vitrina" transformou o lugar numa espécie de estufa. O noticiário jornalístico da noite ratificaria a suspeita de alguns folióes: o dia 26 de dezembro de 2013 foi o mais quente do ano.

Ao longo de duas horas e quarenta minutos, tempo marcado em meu relógio, a folia rezou. Embora fosse notório o forte calor do lado externo da casa, a sensação térmica do lado de dentro ultrapassava os $40^{\circ} \mathrm{C}$. A indumentária dos foliões, confeccionada com tecido sintético, impedia o resfriamento pela transpiração do corpo e, somada ao peso dos instrumentos e à posição estática e repetitiva da "ladainha" (chamada de "cantoria" pelos foliões), contribuía para o clima sufocante. Vários foliões passaram mal durante o rito. Posteriormente, o Sr. Antônio Venâncio, o mestre folião, me lembraria que precisou fazer uma reza bonita, pois ficou devendo uma visita no ano anterior. Então, a reza desse ano teria que ser mais elaborada. De fato, aquela longa reza explorou detalhes da jornada dos Reis Magos em direção ao local de nascimento do menino Jesus que poucas vezes ouvi em outras visitas. Como fiz notar em meu caderno de campo, "foi importante ter passado por essa experiência; ela ajudou a desenvolver a percepção dos limites que o corpo enfrenta na missão". E mais, a percepção de que o mito se misturava ao rito também ganhava expressão, pois tornava claro o fato de que a performance ritual, vivida naquele momento, restaurava o drama mítico vivido pelas personagens bíblicas. Em outras palavras, de novo recorrendo às minhas anotações de campo, naquele momento passei a entender "na pele" que "o sacrifício ou martírio que, por

l Agradeço ao mestre Antônio Venâncio o acolhimento em sua família, e a todos os integrantes da folia Estrela Guia pela "graça" de suas companhias, e também ao Marcus Venitius Bonato Filho, bolsista de iniciação científica (UFF-CNPq) que dividiu comigo a "dádiva" do trabalho de campo. Aproveito ainda para agradecer aos amigos Ana Maria Marques, Edilberto Fonseca e Sandra Pereira Tosta a leitura atenciosa, e aos avaliadores pelos comentários enriquecedores a este ensaio. Os nomes dos anfitriões/devotos são fictícios e colocados entre aspas. 
vezes, o corpo enfrenta durante a jornada serve para lembrar o martírio e o sofrimento vividos por Jesus, José e Maria, bem como pelos três Reis Magos, pois a folia vive, nestes momentos, situações semelhantes às que os Santos bíblicos viveram".

Esse episódio, que me serve de introdução, reúne os principais elementos que formam o objeto da análise desse ensaio. Importa destacar nesse relato, resultado da observação participante junto à folia de reis Estrela Guia durante as jornadas de 2012 e 2013, o significado do corpo enquanto performance verbal e gestual no curso do processo ritual. ${ }^{2}$ As jornadas, também conhecidas como "giro", podem ser definidas ritualmente como um momento no qual se vive uma experiência dramática, extraordinariamente densa, grávida de motivações religiosas e de disposições corporais que duram 13 dias. ${ }^{3}$ Seu início é na virada do dia 24 para o dia 25 de dezembro, tempo de abertura do rito, e término à meia-noite do dia 06 de janeiro, com o rito de "fechamento", dia de celebração dos Santos Reis, conforme o calendário cristão. ${ }^{4}$ Ao longo desse período, intercalado pelo repetido movimento das "marchas", da "visita", da "roda" e do "pouso" realizado pelas folias, ${ }^{5}$ o corpo adquire notória expressão gestual e emocional, nos deixando ver quanto é fundamental a compreensão de sua performatividade enquanto corporeidade, revelando-se um dos fundamentos das folias. ${ }^{6}$

Minha hipótese é que, por trás do sistema da dádiva, haverá uma economia simbólica dos gestos que lhe dá "corpo". Afinal, como Durand citando Mauss, “acredito firmemente que a primeira 'linguagem', o 'verbo', é expressão corporal" (1998: 75).

2 É comum as folias serem identificadas pelo nome dos mestres foliões. A Estrela Guia não foge à regra, sendo conhecida à época como a "folia do Randolphinho". Randolpho Lopes Filho (1940-201 1), devoto dos Santos Reis, foi um importante e respeitado mestre folião de Massambará, distrito de Vassouras (RJ), cidade na qual exerceu o cargo de presidente da Câmara dos Vereadores por dois mandatos consecutivos. As histórias em torno de sua sabedoria e autoridade de mestre folião, por vezes, ganham um colorido mítico. Mas, desde 2012, o mestre Antônio Venâncio passou a guiar a folia.

3 Embora os conceitos de drama e tragédia sejam distintos, aqui penso a experiência dramática das jornadas no sentido dado por Nietzsche ao trágico enquanto modo de dizer sim à vida, sem medo do sofrimento e da dor.

4 Algumas folias voltam a sair no dia 20 de janeiro, dia de S. Sebastião, santo padroeiro do Rio de Janeiro.

5 A “visita” e a "roda" são retomadas à frente; para uma visão de todo o processo, consultar Rocha (2014).

6 O corpo concebido como "fundamento" torna-se sujeito da cultura e não seu objeto apenas. Para Csordas (1990), o corpo, ou melhor, a corporeidade entendida como paradigma não dualista, portanto não dividida entre razão e emoção, matéria e espírito, etc., confere ao corpo a qualidade de sujeito da cultura. Mauss, parece-me, antecipa a superação dessa dualidade, ponto esse de discordância com Csordas, para quem Mauss manteve a fragmentação corpo/pessoa. 


\section{CORPO E ALMA DA RECIPROCIDADE}

Não por acaso, encontro em Marcel Mauss (1872-1950) a principal fonte de inspiração desse ensaio, pois o sacrifício, a prece, a expressão dos sentimentos, as técnicas do corpo, a dádiva, temas e objetos analisados pelo etnólogo francês, parecem reunidos no mundo ritual das folias. Atenção especial é dedicada ao corpo, na medida em que assume um lugar estrutural em sua antropologia, a exemplo do fato social total consagrado no clássico "Ensaio sobre a dádiva" (2003 [1925]). Em estudo anterior, salientei que o corpo "se apresenta como a inscrição fenomenológica de seu pensamento. O corpo é a medida empírica do concreto, o que faz do homem um ser de 'carne e osso', e não uma abstração" (Rocha 2011: 79). No ensaio "As técnicas do corpo", originalmente uma palestra proferida aos psicólogos em 1934 e que é para muitos o embrião da antropologia do corpo, Mauss confere a este a qualidade de ser "o primeiro e o mais natural instrumento do homem" (2003 [1934]: 407) e, como tal, seu objeto e meio técnico. Assim, o corpo é tanto objeto quanto sujeito da cultura, numa palavra, um conjunto de técnicas cujo significado não se reduz à ideia de instrumento, mas atos tradicionais e eficazes que não diferem da experiência mágica, religiosa, simbólica. Em outras palavras, as técnicas corporais ou a "arte de utilizar o corpo" são o resultado de processos educativos transmitidos tradicionalmente. Andar, nadar, correr, dormir, etc., mais do que simples atos e gestos naturais, são técnicas desenvolvidas ao longo da história, por meio da educação. O corpo, então, é menos uma questão de biologia do que a soma desses elementos. Mais do que um dado natural, é o uso ou a maneira como o homem dele se serve que permite pensar o corpo como fato social total. De resto, Mauss adverte ainda para o fato de que a apreensão das técnicas do corpo deve ser orientada pelo tríplice ponto de vista do "homem total". Nas folias, o corpo e a dádiva formam uma combinação que lembra a relação corpo e alma; o corpo se erige, então, em sistema de gestualidades complementares às obrigações de dar, receber e retribuir. Essa relação será reafirmada ainda com a observação de Mauss acerca da existência de uma quarta obrigação: "o presente dado aos homens em vista dos deuses e da natureza” (2003 [1925]: 203). Os gestos de orar, pedir, ofertar, agradecer, acionados nos ritos de sacrifício e nas preces, podem ser incorporados à dádiva e compreendidos como a sua objetificação performativa. ${ }^{7}$

7 Apesar da aparente impressão de fragmentação e inacabamento, a obra de Mauss forma uma "totalidade" relativamente coerente e integrada, na qual o Manual de Etnografia (Mauss 1993) apresenta afinidades com o "Esboço de uma teoria geral da magia" (Mauss e Hubert 2003 [1904]); o "Ensaio sobre a dádiva" (Mauss 2003 [1925]) deve ser visto em conjunto com o "Ensaio sobre a natureza e função do sacrifício" (Mauss e Hubert 1981 [1899]) e "A prece" (Mauss 1981 [1909]). O mundo das ideias se alimenta da experiência concreta, a economia se mistura à religião, a estética à moral, sugerindo assim uma perspectiva interacionista de explicação dos fenômenos sociais em que a ação simbólica se retroalimenta das representações sociais e vice-versa. 
O sociólogo Alain Caillé reconheceu o caráter provisório e especulativo da quarta obrigação no "Ensaio", e destacou: "Alguns amigos ou comentadores nos chamaram a atenção com boas razões para o fato de que não se poderia compreender o dom sem o pedido, e mais que três tempos, o sistema do dom comportaria quatro, organizados em dois pares, o pedido e o dom que o atende, a recepção do dom e a sua retribuição. Note-se que é sobre a quintessência cristalizada do dom, sobre a oração, que deveria tratar a tese de M. Mauss" (2002: 304). Ao aproximar oração e dádiva, Caillé nos convida a pensar o pedido como um gesto. Mas todo o complexo sistema de gestualidades está incompleto sem o sacrifício, na medida em que remete para a simbólica gestual da oferta. Portanto, as obrigações de dar, de receber e de retribuir, incorporadas nos atos de ofertar e de rezar, revelam uma economia simbólica dos gestos na qual se evidencia o princípio da reciprocidade que sustenta e regulamenta todo sistema da dádiva. Tal economia simbólica forma o que estou chamando, numa clara referência a Durkheim e Lévi-Strauss, de "gestos elementares da reciprocidade". 8

Mesmo que cada gesto expresse uma função social específica, deve ser visto como parte do complexo sistema da dádiva, no qual o verbo e o gesto se retroalimentam. Segundo Mauss, "[n]o fundo, tudo aqui se mistura, corpo, alma, sociedade" (2003 [1924]: 336). Nestes termos, a eficácia simbólica da dádiva reside na ação inscrita nos gestos que a objetificam. ${ }^{9}$ Mauss se interessa tanto pela ação quanto pelo seu resultado. Assim, o ato de dar se revela tão importante quanto o que é dado, o ato de receber quanto o que é recebido, o ato de doar quanto o que é doado, o ato de ofertar/sacrificar quanto o objeto sacrificado, enfim, o ato de pedir/agradecer quanto a graça alcançada. Então, o corpo (e seus gestos, suas técnicas, suas emoções, enfim, sua hexis ${ }^{10}$ ), sob a inspiração da noção de fato social total, constitui-se o fato privilegiado a partir do qual se pode apreender o sistema da dádiva, bem como o "homem total" de Mauss, sendo as folias de reis "funcionalmente" exemplares a esse propósito. ${ }^{11}$

8 Numa definição simples, "chama-se de reciprocidade o processo pelo qual as prestações são trocadas na modalidade da dádiva e da contradádiva”, observam Laburthe-Tolra e Warnier (1997: 345). Essas considerações têm como referência as folias de reis; contudo, acredito, pode-se estender tal perspectiva a outras manifestações.

9 A dádiva é coextensiva do símbolo, o que faz dela o fundamento da vida social - ver Godbout (1999) e, principalmente, Caillé (2002), que defende a dádiva como terceiro paradigma.

10 Tomo em Bourdieu (2006: 86) a noção de "hexis corporal", por ele apreendida de Mauss, somente para reforçar a ideia de um "jeito" de corpo, resultado de um processo fenomênico/morfológico de educação e socialização.

11 O "homem total" de Mauss, ao mesmo tempo biológico, psíquico e sócio-histórico, pode ser apreendido, tridimensionalmente, a partir de suas reflexões em "A expressão obrigatória dos sentimentos" (1981 [1921]), “Uma categoria do espírito humano: a noção de pessoa, a de 'eu'” (2003 [1938]) e "As técnicas do corpo" (2003 [1934]). Também Rogério Rodrigues (1997) pensa "As técnicas do corpo" como um dos ensaios basilares na antropologia de Mauss, o que reforça a hipótese da centralidade estrutural do corpo no pensamento do etnólogo francês. 


\section{ESTRUTURA E LIMINARIDADE}

As folias de reis são algumas das mais significativas manifestações culturais de religiosidade popular do catolicismo brasileiro. Dentre as muitas possibilidades de definição, Carlos Rodrigues Brandão (1983) as concebe como expressão ritual de grupos precatórios (rogatórios) de devotos dos Santos Reis (os três Reis Magos), "viajeiros" que percorrem longas jornadas entre os dias 25 de dezembro e 06 de janeiro, visitando casas, recebendo dádivas, renovando promessas, anunciando festejos, levando esperanças, promovendo graças. ${ }^{12}$ Em média as folias são compostas por cerca de 30 pessoas, de crianças de pouca idade a idosos octogenários. Poucas são as mulheres que realizam as jornadas. Na maioria das vezes, sua participação se restringe à atividade de confecção das indumentárias e, principalmente, ao preparo das refeições no dia do fechamento da jornada e durante as "festas de reis" - também conhecidas como "festas de arremate". ${ }^{13}$

De um modo geral, as folias apresentam grande variedade de organização, estrutura e ritual, como atestam alguns estudos regionais sobre o tema (Bitter 2008). Na esteira das abordagens que pensam as folias de reis como fenômeno social assentado no sistema da dádiva (Brandão 1981; Bitter 2010; entre outros), também o simbólico, o gestual, o ritual, o sacrifício, a expressão obrigatória dos sentimentos, as categorias do entendimento e as técnicas corporais encontram aí significação especial. São temas e problemas que se encontram vivos e reunidos nas folias de reis.

Os foliões, devotos na maioria das vezes, são pessoas de origem humilde, residentes na cidade ou em distritos próximos; se ocupam em profissões diversas, como as de pintor, pedreiro, enfermeiro, auxiliar de serviços no comércio, ou estão aposentados. Quanto à organização, as folias são estruturadas, hierarquicamente, a partir da direção do mestre folião (em outras localidades conhecido também como "embaixador", "capitão", "chefe", "guia”), contramestre, bandeireiro ("alferes"), gerente, instrumentistas e palhaços ("gigante", "boneco", "bastião"). Durante a "jornada" ou o "giro", observa-se na organização da folia a formação de uma espécie de comissão de frente constituída pelo mestre, contramestre, bandeireiro e instrumentistas que tocam sanfona, violão,

12 As "jornadas" ou o "giro" são deslocamentos produzidos pelas folias ao longo de 13 dias. Normalmente o percurso é definido com antecedência, pois é preciso acertar os lugares de "pouso" e refeição, mas também é comum a folia desviar-se temporariamente do percurso, para atender algum devoto que pede uma "visita".

13 São festas realizadas fora do período do ciclo natalino, quando uma folia convida outras para um encontro. Sem exagero, essas festas lembram o potlatch dos índios americanos. Em 2012, o mestre Venâncio promoveu uma grande festa de reis na qual recebeu cerca de dez folias. Durante o encontro, cada uma das folias se apresenta, reza para os "reis" (como se diz comumente) e, na sequência, são convidadas a se sentar à mesa para cear. Tais festas duram a noite inteira e só terminam quando o Sol já está alto. 
pandeiro, triângulo, etc. Normalmente, são eles os que adentram o ambiente da casa; os demais - os foliões da percussão ("bateria") -, permanecem sempre fora da casa, junto aos palhaços. É vedada a entrada dos palhaços nos espaços das residências e igrejas, devendo permanecer na rua, pois, como se sabe, via de regra, os palhaços representam os soldados que, sob as ordens do rei Herodes, perseguem José e Maria com o objetivo de matar o menino Jesus. ${ }^{14}$

As folias se fundamentam em torno do sagrado e do profano, categorias objetificadas na bandeira e na máscara. A bandeira é uma espécie de estandarte, símbolo totêmico feito de madeira, papel, plástico e objetos de adorno como pisca-piscas, fitas, etc., e imagens de passagens bíblicas. Por definição, é objeto sagrado e símbolo do "fundamento" das folias; para os devotos, a bandeira é portadora de agência. Conduzida na frente, garante a proteção ao grupo dos foliões e aos devotos dos Santos Reis, tanto no curso da marcha nas ruas, quanto no espaço interior das casas. Contrapondo-se à bandeira, a máscara é o símbolo dos palhaços que, via de regra, representam o lado mundano, o perigo, o mal à espreita. Todas as vezes que a folia abre, iniciando sua marcha, os palhaços devem pedir proteção e, no encerramento, devem agradecer. Após a reza, os palhaços entram em cena. Tendo permanecido do lado de fora da casa, passam então a declamar seus versos decorados (raros são os versos de improviso) e a executar seus acrobáticos saltos mortais e as suas danças performáticas. Esse momento é conhecido como "chula". Para a população, em geral, é o momento mais esperado durante a visita de uma folia a uma residência qualquer, pois o "chula" acontece na rua ou áreas abertas contíguas à casa. É quando os palhaços, combinando dança e performance verbal, narram fatos extraordinários, tecem homenagens a algumas personalidades, fazem críticas sociais aos problemas do país, na maioria das vezes tudo com muita graça e riso acompanhados de saltos acrobáticos. Mas essa dualidade que estrutura a organização das folias em torno da bandeira e da máscara, do sagrado e do profano, da ordem e da desordem, somada à sua condição viajante, revela-se menos opositiva do que ambígua, fazendo delas fenômenos liminares, como sugere Turner (2008). Muitas vezes as fronteiras são relativizadas permitindo a combinação da devoção com a carnavalização.

Presentes em vários estados da nação, as folias têm grande relevância cultural na região centro-oeste e sudeste do país. Para Adriana Rattes, ex-secretária de cultura do estado do Rio de Janeiro, as folias de reis são "um dos alicerces da cultura tradicional" fluminense (Coutinho e Nogueira 2009). A cidade de Vassouras (RJ) é, nesse caso, exemplar. Localizada no "Vale do Café", a cerca de 110 quilómetros da capital fluminense, Vassouras abriga rico acervo histórico

14 Apesar da aparente generalização em torno das folias, essa caracterização parte da experiência junto ao grupo da Estrela Guia. Em algumas localidades os palhaços são vistos como protetores disfarçados do menino Jesus. 
e arquitetônico e intenso movimento de folias de reis durante as festividades de Natal, momento em que as folias ganham as ruas e a atenção da população local. É então que a cidade transforma-se em um "grande presépio". ${ }^{15}$

\section{PROMESSA É DÁDIVA}

A folia de reis Estrela Guia é uma das mais tradicionais da cidade de Vassouras, com mais de 40 anos de existência. A jornada de 2013 teve um significado especial, ao cumprir o ciclo de uma promessa. A história da bandeira que a folia conduziu até aquele ano começou com a obrigação feita por José dos Santos, devoto dos Santos Reis e antigo folião, residente em Paty do Alferes (RJ), que mandou produzi-la com o objetivo de saldar uma dívida. Passados três anos, o Sr. José dos Santos adoece e, antes de vir a falecer, pede ao compadre "Randolphinho" que conclua a sua promessa. Dois anos depois, é este quem, pressentindo a morte, transfere a bandeira para o amigo e mestre folião Antônio Venâncio. Ao longo de sete anos, cumprido o tempo da promessa, a bandeira Estrela Guia foi levada ao Santuário de Bom Jesus de Matosinhos (RJ), no dia 06 de janeiro de 2013, dia de Reis, para lá permanecer definitivamente na sala dos milagres. ${ }^{16}$

O processo de transmissão da bandeira na folia constitui uma importante ação simbólica por meio da qual se reafirma o sistema de reciprocidade da dádiva. O pagamento de promessas nunca é um ato isolado e sem consequências, ao contrário, aciona todo um sistema de compadrio e de ajuda mútua entre os foliões da região. Comumente se diz que promessa é dívida, porém o correto nas folias, dada a profundidade da obrigação, é que promessa é dádiva.

A promessa constitui um compromisso entre os homens e os deuses. A obrigação de retribuir a graça recebida, ou a esperança de alcançá-la é o que motiva os homens a se projetarem no tempo; afinal, se obtida a "graça", um dia o devoto deverá saldar a dívida com o santo. ${ }^{17}$ Ela cumpre um destino e, por mais que à primeira vista seja o resultado de uma iniciativa ou ação individual espontânea, termina por mobilizar um número grande de pessoas ao redor. Como no caso da prece, a promessa é o eco de uma instituição, o símbolo da

15 Durante o Brasil Império, Vassouras desenvolveu-se econômica e culturalmente, tornando-se centro de produção cafeicultora e região de veraneio dos membros da família real e da corte. O registro dessa opulência pode ser acompanhado no "clássico" Vassouras do brasilianista Stanley Stein (1990).

16 Sete é número cabalístico e, segundo a Maçonaria, "representa a plenitude ou o pleno (sete maravilhas, perdoar sete vezes, sete dias da semana, etc.); entendemos, porém, que uma promessa deverá ser paga plenamente. Razão que levam $[s i c]$ os foliões a homenagear o santo que prometeu durante sete anos, tanto em Folia de Reis quanto em Folias de outros santos segundo a tradição". Assim o mestre folião Ronalt Aguiar Santiago, mais conhecido como Roninho, da Região dos Lagos (norte do Estado do Rio de Janeiro), me explicou o tempo das promessas.

17 A promessa é, sem dúvida alguma, exemplo da quarta obrigação de que fala Mauss (2003 [1925]): em termos sociológicos, uma forma de mediação entre os homens e os deuses. 
devoção, fragmento de uma história de longa duração. As folias são organizações culturais de base familiar, não só porque mantêm a tradição através da hereditariedade (passando de pai para filho) ou porque envolvem primos, cunhados, tios, mas também porque promovem o sentimento de família na reunião dos foliões, por meio de relações afetivas e simbólicas de irmandade, amizade, convivialidade, respeito. Essa comunidade de sentimentos favorece a socialização da promessa. Não se caracterizam como grupos de ajuda mútua no sentido estrito do termo, como acontece com as tabancas cabo-verdianas (Trajano Filho 2009), mas além de propagarem a "história verdadeira", como me disse Sr. Antônio Venâncio, referindo-se à Bíblia, eventualmente socorrem algum folião ou mesmo outras folias. Os motivos que levam as pessoas a participarem das folias são diversos, desde a sedução festiva ou a garantia de aventura na visão dos mais novos às promessas feitas e às graças obtidas referentes a um problema de saúde, à aquisição de bens como, por exemplo, a casa própria, à conquista de um emprego, etc.

A história de promessa da bandeira Estrela Guia aponta para um conjunto de fatos importantes na estrutura e organização das folias: primeiro, mesmo que a promessa se apresente como ação individual, carrega uma dimensão coletiva; segundo, comumente a promessa é transferida aos amigos e parentes - o que faz das folias de reis um fenômeno marcado por relações de parentesco; terceiro, as promessas expressam um modo de relacionamento devido aos deuses e aos homens que se observa por meio da quarta obrigação - assim anunciada por Mauss no "Ensaio sobre a dádiva"; quarto, tudo isso nos leva a concordar com Turner quando diz que "é preciso discutir esta questão da peregrinação como obrigação e como ato voluntário, envolvendo um voto, ou como se diz na Iberoamérica, 'uma promessa'" (2008: 162); por fim, a promessa evoca o tema do sacrifício e da prece, formando um sistema mais ou menos integrado com a dádiva, o corpo, os gestos e as emoções. A dádiva apresenta afinidade com a religião no sentido mais elementar da palavra: religare. ${ }^{18}$

\section{O GESTO ORIGINAL}

Os gestos têm sempre uma dimensão física (técnica), psíquica (emocional), histórica (educação), simbólica (mítica), estética (ritual), política (poder), social (moral) e podem ser vistos como atos de criação. Para Jean-Loup Rivière:

"O gesto é a linguagem que mais se aproxima da possibilidade de indiferenciação, embora institua a irredutível diferença. É por isso que é, tal como aconteceu quanto ao indo-europeu para alguns no século XIX, um criador 
eficaz de mitos sobre as origens. Esta conjunção do desvio e da identidade é a mesma que conjuga, para o homem, as forças de vida e da morte. Se o gesto é essa prática que organiza sem nós (porque a gestualidade elabora-se a partir de códigos preexistentes), o capital físico do nosso corpo, a necessidade que leva certos autores a transformá-lo numa linguagem expressiva e espontânea ('exprimo-me nos meus gestos') é a mesma que leva a ocultar a ruptura original. Os mitos da origem e da linguagem gestual natural reúnem-se para conjurar a morte" (1987: 13).

Os gestos são, por definição, performance; nos termos de Turner (1988), a performance é entendida como uma "sequência complexa de atos simbólicos" portadora de qualidade reflexiva, portanto ação simbólica capaz de revelar o homem para si mesmo. No sentido nietzscheano referido em nota atrás, performances podem ser vistas como experiências dramáticas capazes de provocarem desarmonias criadoras e o corpo se erige como suporte simbólico par excellence nesse processo. Os gestos, então, são expressões comportamentais de grande significação; são veículos de ideias, valores e práticas; do ponto de vista mítico, são atos simbólicos de fundação. Com efeito, antes de se ver no gesto apenas um movimento, o resultado de uma mecânica ou uma simples ação, sua verdadeira natureza reside na qualidade de estabelecer relações, de promover a sociabilidade, enfim, de produzir sentido. $\mathrm{O}$ simples gesto de estender a mão, um leve aceno de cabeça, um sorriso enigmático dizem mais do que mil palavras; afinal, piscadelas de olho podem revelar teorias, nos ensina Geertz (1989). Por sua vez, Câmara Cascudo nos lembra que "o gesto é anterior à palavra. Dedos e braços falaram milênios antes da voz. [...] Sem gestos, a palavra é precária e pobre para o entendimento temático" (1987: 10). O gesto é uma expressão simbólica da relação humana, sua compreensão exige o compartilhamento de significados comuns. Sua manifestação é a expressão real e concreta de uma ação corporal não vocalizada. Mas, mesmo a voz, o canto, a prece, são gestos verbais, nos revela Csordas (1990) em sua análise da glossolalia entre os cristãos carismáticos. Enquanto linguagem, os gestos invariavelmente se dirigem ao "outro". ${ }^{19}$

19 Mas nem sempre os gestos gozaram de prestígio entre os homens, principalmente os clérigos do período medieval, que viam nele um sinal do diabo. É o que diz Le Goff em "Os gestos do Purgatório": "As nossas pesquisas levam-nos a pensar que o cristianismo da Alta Idade Média achou suspeita a gesticulação: a própria palavra gestus passou por um eclipse entre os séculos V e XII. 'Gestos' faz pensar em dois domínios particularmente detestados pelos cristãos, que neles davam vigoroso combate às sobrevivências pagãs: o do teatro e o da possessão diabólica. Os especialistas do gesto - os mimos ou os possessos - eram vítimas ou cúmplices de Satanás. A milícia do Cristo era discreta e sóbria nos gestos. O exército do Diabo gesticulava" (1994: 150). No campo da política moderna, os gestos tornaram-se símbolos do poder, sendo a própria agência de institucionalização do poder, observa Haroche (1998). A etiqueta no Antigo Regime irá revelar a gramática do poder inscrita no jogo da aparência dramatizado nos salões da sociedade de corte. 
$\mathrm{Na}$ "moral dos gestos", observa Schmitt, "os movimentos exteriores do corpo traduzem os movimentos interiores da alma" (1995: 152). Os gestos expressam, numa aproximação à ideia de "significante flutuante" apontada por Lévi-Strauss em sua "Introdução à obra de Marcel Mauss" (2003 [1950]), o símbolo em estado puro capaz de desempenhar a função semântica de permitir que o pensamento se exerça e se faça agência. Não por acaso, a epígrafe que abre este texto enuncia: “... sem a iniciativa de um gesto gracioso [...] nada pode existir” (Godbout 1999: 157).

A "visita" seguida da formação da "roda" são situações cronotópicas ricas para a observação dos gestos como será visto à frente e, como tal, representam um convite para se penetrar no vasto mundo de significados e de gestualidades. ${ }^{20} \mathrm{E}$ a antropologia interpretativa de Clifford Geertz (1989), com sua proposta etnográfica de "descrição densa", constitui, nesse momento, uma fonte de inspiração metodológica para a sua análise. Compreendendo a cultura como "teias de significados" que o próprio homem teceu; Geertz entende ser o ofício do antropólogo a sua interpretação por meio da descrição densa, ou seja, o que o antropólogo faz é descrever de maneira microscópica (detalhada e profunda) um fato da vida social com o objetivo de apreender as estruturas de significação (códigos historicamente construídos) presentes na cultura. Assim, segundo o antropólogo, a "tarefa essencial da construção teórica não é codificar regularidades abstratas, mas tornar possíveis descrições minuciosas; não generalizar através dos casos, mas generalizar dentro deles" (1989: 36). Pequenos gestos e eventos podem ser reveladores de profundas estruturas de significação social. É o que faz, então, da gestualidade dramatizada nas jornadas dos Santos Reis um fato de valor paradigmático. ${ }^{21}$

\section{A MORADA DA PALAVRA}

A "visita" marca o encontro dos foliões na residência do devoto; é um dos momentos mais importantes no processo ritual das folias de reis. Fazendo alusão ao subtítulo do "Ensaio sobre a dádiva", a visita pode ser vista como a forma e a razão das trocas simbólicas desse fenômeno social total. É o momento em que, efetivamente, o folião estabelece suas trocas com o devoto. Numa conhecida passagem do "Ensaio", Mauss observa: "o que eles trocam não são exclusivamente bens e riquezas, móveis e imóveis, coisas economicamente úteis. São, antes de tudo, amabilidades, banquetes, ritos [...]" (2003 [1925]: 191). Esse quadro de sociabilidades puras (entendidas como interação

20 Tomo emprestado de Bakhtin (1993) o termo cronotopo, por ele empregado na crítica literária, para pensar a "visita" e a "roda" como situações espaço-temporais que condensam uma enorme gama de representações e práticas sociais.

21 O limite desse ensaio me obriga a destacar neste momento somente os gestos mais rotineiros performatizados durante as "visitas". 
no sentido simmeliano) e reciprocidades é favorecido pela instauração do que Turner (2008) entende por communitas, ou seja, uma situação liminar que favorece a formação de um tipo de relação social não estruturada. É então que os homens se encontram consigo mesmos e com os outros, com os deuses e os santos, sendo as jornadas, as peregrinações, as romarias o caminho que os leva à communitas. As dificuldades e os perigos são muitos e, apesar deles, o caminho se mostra uma promessa de aventura e de abertura para o mundo. De acordo com Victor Turner:

“À medida que o peregrino se afasta dos envolvimentos estruturais do lar, seu caminho se torna cada vez mais sacralizado em um nível e cada vez mais secularizado em outro. Ele encontra mais templos e objetos sagrados durante seu progresso, mas também enfrenta perigos reais como bandidos e ladrões. Ele precisa atentar para a necessidade de sobrevivência e frequentemente consegue dinheiro para se transportar, e passa também por mercados e feiras, especialmente no fim da jornada, quando o santuário é cercado pelo bazar e pela feira de diversões. Mas todas essas coisas são mais contratuais, mais associativas, mais volitivas, mais prenhes do novo e do inesperado, mais repletas de possibilidades de communitas, como o companheirismo e a camaradagem mundana e a comunhão sagrada, do que qualquer coisa que ele tenha experimentado no seu local de origem. E o mundo se torna maior" (2008: 171).

A "visita" apresenta uma estrutura que se repete em todas as casas, embora nenhuma seja exatamente igual à outra. Assim, no dia 04 de dezembro, ao pôr do Sol, a bandeira Estrela Guia se dirigiu à cidade de Mendes (RJ), distante cerca de 40 quilómetros de Vassouras, com o objetivo de fazer a última visita do dia, e única naquela localidade. Devoto dos Santos Reis, todo ano o Sr. "Renato" recebe a folia em casa; porém, naquele ano, o clima não era o mesmo dos anos anteriores. Tão logo o ônibus chegou à localidade, a sua filha adiantou-se no encontro com os foliões solicitando que o grupo se dirigisse à sua casa, pois o pai, sofrendo de uma moléstia na perna, já não podia mais se locomover por grandes distâncias.

Organizada a folia, o mestre Antônio colocou-a em marcha dirigindo-a a casa do devoto. No caminho, a folia canta em coro Quem é este povo?, hino cristão mais conhecido pelo verso "Vai morar, vai morar com Jesus lá no céu". Os membros da família recebem a folia na porta da casa, tomados de grande emoção. $\mathrm{O}$ bandeireiro se adianta e um membro da família se aproxima: toca a bandeira, beija-a e a toma em suas mãos, já que o dono da casa não pode fazê-lo. A bandeira é levada para o interior da residência, a folia segue atrás cantando. A decoração é simples, poucos móveis enfeitam o espaço da sala que acaba sendo ocupada por cerca de dez pessoas, folióes e devotos. Em um 
canto, próximo à porta que leva ao interior da casa, encontra-se uma mesa que sustenta o presépio. Sr. Antônio apita e a música é interrompida. A bandeira é colocada nas mãos do devoto que, sentado, permanece de frente para ela, deixando-se tocar na cabeça com os olhos cerrados. Como nos lembra Câmara Cascudo, gestos como esses, de baixar a cabeça e cerrar os olhos, são sinal de respeito, subserviência, devoção, alheamento do mundo, seguido de introspecção. É quando o devoto dá curso à "viagem invisível da meditação" (1987: 26). Sr. "Renato" chora muito, bem como seus familiares. Por certo, nesse momento, ele pede uma "graça" aos Santos Reis. ${ }^{22}$ Então, o sanfoneiro puxa a reza que será conduzida pelo mestre da folia e repetida pelo coro dos foliões que tocam os instrumentos de acompanhamento. Sem poder reproduzir toda a longa reza, destaco algumas passagens que ilustram esse drama ritual:

"Pai, Filho e Espírito Santo com amor e alegria

Jesus, José e Maria

Minha bandeira chegou na sagrada moradia

Jesus, José e Maria

$\mathrm{Na}$ chegada da bandeira os devotos se comoveram

Jesus, José e Maria

Maria também chorou quando Bom Jesus morreu

Jesus, José e Maria

Peço a Deus inspiração nesse sagrado momento

Jesus, José e Maria

Pra mim rezar um trechinho do sagrado nascimento

Jesus, José e Maria

$[\ldots]$

Eu cheguei na sua casa com o sagrado Santo Rei

Jesus, José e Maria

Eu vim de muito longe só para visitar você

Jesus, José e Maria

Vim rezar na sua casa com as palavras da verdade

Jesus, José e Maria

Porque o Senhor é meu amigo nós temos muita amizade

Jesus, José e Maria

O devoto segurou nossa bandeira sagrada

Jesus, José e Maria

E no reino da salvação tem morada reservada

Jesus, José e Maria

Deus vos salve lindo Presépio com todas as imagens que são

Jesus, José e Maria 
$[\ldots]$

Minha bandeira se despede inté para o ano que vem

Jesus, José e Maria

Se a morte não nos matar e se Deus quiser também

Jesus, José e Maria

Agora peço saúde pra todos da moradia

Jesus, José e Maria

Entregai a nossa bandeira que ela é a nossa guia

Jesus, José e Maria”

[O mestre apita, colocando fim à reza.]

A reza é, ao mesmo tempo, a evocação de passagens bíblicas e um pedido de boa saúde para toda a família. O clima é de muita comoção. O comportamento dos foliões e dos devotos é marcado por toda uma gestualidade comedida que expressa o encontro dos homens com o sagrado. A reza do mestre folião é um canto que mais lembra uma ladainha, um lamento ou uma súplica, tal a performance vocal por ele realizada. ${ }^{23}$ A feição do rosto muda, a voz é projetada para o alto numa sonoridade metálica e melancólica. Nesse momento, o verbo encompassa o gesto. E a julgar pelo tom aparentemente informal que a reza assume, ela se transforma num diálogo com os santos. Ao final do verso, mestre Antônio abaixa a cabeça, cerra os olhos e abraça o violão, aguardando o acompanhamento da bateria e o coro dos foliões. O corpo permanece a maior parte do tempo imóvel, os movimentos quando os há são um prolongamento dos instrumentos. A cena só é quebrada, de vez em quando, durante a circulação de copos de água para os foliões. Todo o grupo de foliões canta numa profusão de vozes, formando um coro meio dissonante. É um momento mágico em que vemos a combinação da communitas de Turner com a observação de Mauss segundo a qual, "no fundo", tudo se mistura. "Misturam-se as almas nas coisas; misturam-se as coisas nas almas. Misturam-se as vidas, e assim as pessoas e as coisas misturadas saem cada qual de sua esfera e se misturam [...]" (2003 [1925]: 212). A reza dura mais de uma hora, e durante todo esse tempo o clima de comoção permanece.

Embora toda essa gestualidade seja repetida várias vezes por dia, durante dias seguidos, e por anos a fio, cada visita é sempre diferente da outra, é sempre única. E mais, não se trata de uma mera representação, o momento da reza é, de fato, um momento de ação simbólica, de comunicação entre

23 Talvez não seja exagero ver na performance verbal do mestre folião um ato ilocucionário (Austin 1990) que nos aproxima dos ritos mágicos; afinal, a palavra, o canto, exercem poder sobre objetos e pessoas, observam Mauss e Hubert (2003 [1904]). Também Lévi-Strauss (1967), em estudo clássico sobre a magia, destaca o papel da linguagem, chamando a atenção para os rituais encantatórios, como missas e sessões de cura, onde o padre ou o xamã fornecem ao doente um mito, uma linguagem a partir da qual ele pode organizar e formular suas dores, ansiedades, enfim, um sentido para a sua "má sorte". 
os homens e com os santos. Não se trata de um discurso sobre o mito, mas de um discurso transitivo direto. O verbo se faz "carne". ${ }^{24}$ As rezas, então, também chamadas pelos foliões de "partidas", "cantorias" e, eventualmente, "toadas", ilustram essa forma de avatar, como se pode ver no ritual de fechamento da folia:

"É hora de agradecer os Três Reis da adoração

Soldados de Herodes vocês estão me escutando

- Jesus, José e Maria [coro]

Tire seis capacetes

Venha cá que eu vou chamar

- Jesus, José e Maria [coro]"

Em contraposição à ideia de representação, as folias abrem espaço para a presença do fenômeno mimético em que a imitação não é, exatamente, uma cópia. Como têm apontado alguns estudos sobre mimesis e performance (Chaves 2008), a partir do momento que o folião veste a sua indumentária (seja o "blusão" do folião ou a "farda" de palhaço) se vê imbuído de atributos semelhantes aos das personagens bíblicas. Assim, ao colocar a máscara o palhaço se investe do significado dos soldados de Herodes, mas, dialeticamente, deles se diferencia porque passa a ser um "outro". ${ }^{25}$

Reunindo-se com o sagrado, com o seu próprio "eu" e com o "outro", nesse momento marcado pelas expressões obrigatórias dos sentimentos e técnicas corporais, o folião parece se revelar aos nossos olhos um "homem total". Sem dúvida alguma, é o momento ritual mais importante da constituição da identidade do folião, que não se reduz à religiosidade, pois se estende à dimensão social, moral, política, etc. ${ }^{26}$

O término da reza não significa o fim do processo ritual. Após esse momento intermediário, o devoto oferece a sua contradádiva. A retribuição é feita na forma de comida: a folia recebe farto lanche (cachorro-quente e refrigerante). Posteriormente, o devoto ainda faria uma doação em dinheiro. É então que sou apresentado ao Sr. "Renato", dono da casa, que se diz devoto dos Santos Reis

24 A fusão de sentidos que a folia produz sugere uma aproximação com a ideia de "carne" em Merleau-Ponty (1992), entrelaçamento do corpo com o mundo, mas este é um ponto a ser aprofundado em outro momento.

25 A cada vez que se visita uma casa, reiterando o sentido da repetição, na verdade um novo sentido é criado, produzindo a diferença. A repetição não é cópia mas recriação. Em outro momento destaquei a importância da indumentária, entendida como parte de um sistema de objetos (vestuário, máscaras, adereços) que compõem a identidade cultural dos foliões: o ato de "vestir o uniforme ou a farda na folia, portanto uma 'roupa especial' investida de valor simbólico e ritual é, na verdade, vestir um tipo de 'persona' ('pessoa')" (Rocha 2014: 13).

26 As folias de reis de Vassouras vivem, em sua maioria, um momento de resistência cultural frente ao descaso e à falta de políticas públicas do poder local instituído, denunciam os foliões. 
há mais de 40 anos, tendo sido, inclusive, folião no passado. Agora, acometido por uma moléstia na perna, espera a graça dos santos. Passado o tempo de uma hora mais ou menos, o mestre dos palhaços pergunta ao dono da casa se eles podem brincar. Após o consentimento, todos se preparam para o "chula". É quando se passa da fé para a festa, do sério para a brincadeira, da performance verbal à gestual.

A folia sai da casa, sem dar as costas ao presépio, e passa ao espaço da rua. Forma-se uma grande "roda" na qual a bateria, que na maioria das vezes também permanece do lado de fora das residências, entra em cena, orquestrada pelo mestre dos palhaços. É o momento do "chula", também chamado de "brincadeira" pelos palhaços que, agora, se tornam os donos da festa. O "chula" é a sequência ritual na qual os palhaços que representam os soldados de Herodes entram em cena declamando versos e realizando verdadeiros espetáculos acrobáticos. Ao contrário do que acontece na reza, no curso do "chula" o corpo adquire enorme mobilidade e visibilidade. Neste momento, os palhaços declamam seus versos, dançam, realizam saltos acrobáticos, tudo sob os olhares atentos da plateia que aplaude ou vaia as suas performances verbais e/ou gestuais. Ocorre uma relativa inversão; afinal, agora, o gesto encompassa o verbo. $\mathrm{O}$ público que assiste parece mais interessado nas performances corporais dos palhaços do que em sua poética, embora atento a tudo. ${ }^{27}$ Os palhaços são personagens portadoras de grande ambiguidade. Seu domínio é o das ruas, porque normalmente são interpretados como representantes do mal. Sobre eles existem muitas estórias que destacam sua vulnerabilidade ao mal, caso desobedeçam a certos preceitos ou quando quebram certas regras ou violam alguns tabus. Os mais velhos aconselham: é bom que se permaneça próximo à bandeira, ela protege. A importância da personagem, reconhecida praticamente por toda a literatura referente ao assunto, merece atenção à parte. ${ }^{28}$

Ao final da brincadeira, acompanhada por dezenas de pessoas das vizinhanças, a "roda" se desfaz, a bandeira de despede e sai em direção ao ônibus que a aguarda para levá-la de volta ao seu ponto de origem.

27 Alguns foliões têm apontado essa mudança performática, pois lembram que antigamente o bom palhaço era aquele capaz de prender a atenção do público pela sua poética; atualmente, os mais jovens constroem sua reputação em torno de suas performances acrobáticas. Nas regiões interioranas (roças), a performance verbal ainda prevalece sobre a corporal; o contrário ocorre no espaço urbano.

28 Por exemplo, são comuns as estórias dos palhaços vítimas de "surras", sem que se possa ver quem as aplica, por terem quebrado alguma regra; ou então, as narrativas sobre visões de "coisas" e "seres" obtidas com a "proteção" das máscaras. A motivação para ser palhaço nem sempre é religiosa, mas muitas vezes social e estética, na medida em que a personagem garante certa "fama" e "prestígio" junto aos jovens. Para uma análise mais densa sobre os palhaços, ver o trabalho de Bitter (2010). É bom que se diga, existe mais de um tipo de palhaço com diferentes estilos ("quebra" é a categoria nativa que expressa essa ideia) - ver Rocha (2014). 
Todo esse processo ritual nos deixa ver um duplo movimento corporal que pode ser sintetizado no quadro $1:^{29}$

Quadro I

Representação sinóptica do processo ritual

$\begin{array}{cccccccc}\text { Cronotopo } & \text { Polo } & \text { Símbolo } & \text { Corpo } & \begin{array}{l}\text { Perfor- } \\ \text { mance }\end{array} & \text { Ritmo } & \text { Ação } & \text { Hierarquia } \\ \text { Visita } & \text { Casa } & \text { Bandeira } & \text { Estático } & \text { Verbal } & \text { Lento } & \text { Rezar } & \begin{array}{l}\text { Verbo encom- } \\ \text { passa o gesto }\end{array} \\ \text { Roda } & \text { Rua } & \text { Máscara } & \text { Flexível } & \text { Gestual } & \text { Rápido } & \text { Brincar } & \begin{array}{l}\text { Gesto encom- } \\ \text { passa o verbo }\end{array}\end{array}$

Embora a "visita" e a "roda" constituam momentos marcados no processo ritual das folias de reis, não se opõem, antes se complementam. Tomando uma vez mais Mauss (2003 [1904-1905]) como inspiração, o movimento das folias de reis em suas jornadas segue uma estrutura de "marchas" e "pousos" (Rocha 2014), que lembra a morfologia sazonal que regula a vida esquimó (Inuit). Nesse sentido, a "visita" e a "roda" parecem celebrar o momento em que a folia passa de um movimento horizontal da jornada, do "giro", para um movimento vertical, de mergulho na cultura, para dentro, em profundidade. Assim, o corpo e a gestualidade que caracteriza a "visita" dão lugar a outra gestualidade que se performatiza na "roda", mas como seu prolongamento. Afinal, o verbo é um gesto e o gesto é uma forma de verbo.

A passagem da reza à brincadeira abre a possibilidade de muitas vezes se passar de uma a outra relativizando as "fronteiras". Assim, ao término da reza a passagem do interior da casa para o domínio da rua pode ser mediada pela oferenda da comida e da bebida pelo devoto/anfitrião. Normalmente, esse momento de comunhão, de descanso, de comensalidade entre os devotos e os foliões ocorre nos espaços fronteiriços, como varandas, garagens, quintais e/ou terreiros, ou seja, espaços intermediários entre a casa e a rua. Então, o corpo e sua gestualidade comedida, lenta, centrada, predominante durante a reza, dará lugar, aos poucos, a outras gestualidades mais excêntricas. Assim, a fina linha que separa formalmente os momentos da reza e da brincadeira é flexível, elástica o bastante para permitir a criação de cenários ou de situações onde as relações são mais dialógicas do que opositivas. Nesse sentido, mesmo que a estrutura das folias seja composta por funções distintas (rezador, tocador, palhaços), enquanto grupo social organizado ela constitui um só corpo com 
expressão gestual diferenciada durante o processo ritual. Em outras palavras, os corpos que giram, que visitam, que descansam, que rezam, que brincam formam um só corpo com muitos gestos.

Por certo, a visita é algo mais denso e profundo do que o simples cumprimento de um costume em nome da tradição folclórica; antes, trata-se de um momento de renovação da fé, de promoção da communitas, de encontro dos homens entre si com os santos e o filho de Deus. Momento de dramatização e reflexividade em que devotos e foliões, pode-se dizer, formam um só corpo -alma. Do ponto de vista sociológico, os homens estão a consagrar o compromisso com a fé, a solidariedade aos devotos e a reciprocidade com os santos. Ao final, todo o drama ritual vivido durante a visita não deixa de ser uma evocação dos gestos míticos de fundação da cristandade ocidental segundo as narrativas bíblicas.

\section{A QUARTA OBRIGAÇÃO}

Nos rituais de religiosidade popular o corpo adquire uma importância capital. É por meio dos gestos comedidos ou exagerados, das expressões de gozo e/ou de renúncia total, das práticas de suplício ou de comunhão que o devoto conversa com os Santos ou com Deus. O corpo é o sujeito dessas performances, comunicações, sociabilidades, trocas simbólicas. Isso fica claro nos ritos sacrificiais de devoção no catolicismo popular brasileiro, observa José Carlos Pereira:

"Além do beijo, como expressão corporal, elencamos também outras formas dos devotos expressarem e demonstrarem o papel do corpo nesta categoria de devoção: subir as escadas de joelhos, contorcendo todo o corpo; rezar com as mãos erguidas na direção da imagem; tocar na mesma; louvar, através de cantos, com gestos e outras manifestações; procissões, com ênfase no carregar o andor com a réplica do santo; ou mesmo a atitude como a de carregar cruzes ou outros objetos pesados, castigando o corpo, como forma de penitência. São linguagens do corpo que falam de uma realidade sofrida. Também os ex-votos não deixam de ser, em grande parte, uma forma de relação corporal com o Santo. O número de partes do corpo que são reproduzidas em cera é bastante significativo nas salas de milagres dos santuários. São expressões simbólicas da linguagem do corpo na devoção" (2004: 64).

Nas folias de reis não é diferente. Os gestos da reciprocidade (dar, receber, retribuir, inclusive pedir/ofertar) são a expressão técnica e simbólica que faz do sistema de regras da dádiva um fenômeno social total concreto. Pode-se começar destacando o fato de que as jornadas vividas ao longo de 13 dias são um 
ritual de grande profusão simbólica no qual o corpo se mostra a toda a prova. Essas jornadas são um misto de aventura e sacrifício. Se, de um lado, os dias passados juntos, em companhia dos amigos e parentes, caminhando por léguas de distância, visitando as moradias de um bairro ou distrito rural, promovem a interação e a sociabilidade do grupo, não sem evitar episódios ou momentos de conflito, do outro lado, a peregrinação de duas semanas longe de casa, deixando a família, os filhos e o conforto do lar, para se viver, no limite, horas a fio de rezas e cantorias, sob o sol escaldante ou fugindo da chuva, dormindo em esteiras ou colchonetes improvisados, dá bem o tom das condições enfrentadas pelos foliões. E nada, nada se compara ao sacrifício imposto ao corpo durante essas jornadas, sendo visível ao final da peregrinação o esgotamento físico e o abatimento psicológico do folião. ${ }^{30}$

Por essa razão, a compreensão de todo o processo evoca os temas do sacrifício e da prece. O sacrifício, juntamente com a prece, evidencia a quarta obrigação: aquela dirigida às relações entre os homens e os deuses. Em princípio, o sacrifício e a oferta feita aos deuses consistem em pagamento à sua generosidade, na medida em que permitem a vida em determinada terra, a exploração de determinado produto, a caça e a pesca de determinado animal e peixe, etc. Neste sentido, o sacrifício é parte do sistema da dádiva, pois, ao mesmo tempo, expressa uma troca simbólica e uma forma de mediação cultural entre os homens e os deuses, o profano e o sagrado. ${ }^{31}$

Para Mauss e Hubert, "o sacrifício é um ato religioso que, pela consagração de uma vítima, modifica o estado moral da pessoa que o realiza ou de certos objetos pelos quais ela se interessa" (1981 [1899]: 151). Na verdade, o que está em jogo nesse processo é a passagem do profano ao sagrado por meio da consagração da vítima. Por meio da imolação da vítima, com sua destruição, se busca atingir o plano do sagrado. Considerando que, como diz Girard, “a violência e o sagrado são inseparáveis" (1990: 33), a destruição da vítima no sacrifício é, ela mesma, um antídoto contra a violência da sociedade. Assim, o rito sacrificial promove a vítima à condição de sagrado e não o contrário. Enquanto ritual, o sacrifício tem na vítima o veículo simbólico de ligação entre o sacrificante e a divindade. O sacrifício, então, pode ser visto como um sistema de comunicação simbólica por meio do qual o sacrificante dramatiza

30 Curiosamente, o folião é tomado de grande excitação no exato momento em que se aproxima o fim da jornada. Os palhaços, estimulados pelos espectadores, parecem investidos de uma força superior que os leva a saltos cada vez mais ousados e acrobacias insólitas; os foliões da bateria tocam seus instrumentos como se participassem de um ritual exótico; ao fim e ao cabo, não se distinguem, às vezes, os sinais de cansaço em meio aos gestos da devoção durante a "reza-canto" dos foliões. Alguns foliões parecem tomados por um êxtase.

31 Mauss e Hubert (1981 [1899]) conferem ao sacrifício uma estrutura composta de entrada e saída, na qual, entre uma e outra dessas ações, se desenvolve toda uma performance protagonizada por personagens (sacrificantes, sacrificadores e vítimas), instrumentos e lugares. 
alguns dos valores básicos da sociedade, sobretudo aqueles relativos à esfera do sagrado e do campo divino. É na tensão que envolve o profano e o sagrado que o corpo se apresenta, invariavelmente, como "sujeito" e/ou "vítima" preferencial do sacrifício. ${ }^{32}$

Nessa linha de reflexão, o suplício do penitente, a imolação da vítima, o sofrimento da pessoa, o martírio corporal, enfim, a "violência contra o corpo" aparece como um aspecto central no rito sacrificial. É que, lembram Mauss e Hubert, sendo o corpo um veículo simbólico de mediação entre o sacrificante e a divindade, é preciso que haja uma relação de afinidade entre ambos, pois "é pelo semelhante que se alimenta o semelhante" (1981 [1899]: 220); afinal, "a vítima tem sempre alguma coisa de divino que o sacrifício põe em evidência" (1981 [1899]: 209).

A prece, como o sacrifício, pode ser vista como parte do sistema de reciprocidade da dádiva, especialmente no plano das relações entre o profano e o sagrado. A quarta obrigação, como sugere Caillé (2002), expressa o ato simbólico de evocar a Deus através da prece e, ao mesmo tempo, de cumprir a graça obtida por meio do sacrifício, movimentos estes reunidos na promessa. Fenômeno social total, a prece é um rito oral complexo, plural, infinito e performático, na medida em que não só aciona um sistema de crenças e mitos mas também exige um conjunto de técnicas corporais na hora de sua prática. "Uma oração não é somente a efusão de uma alma, o grito de um sentimento. É um fragmento de uma religião. Ouve-se ressoar aí o eco de toda uma imensa sequência de fórmulas; é um trecho de uma literatura, é o produto do esforço acumulado dos homens e das gerações" (Mauss 1981 [1909]: 245). É o próprio Mauss quem nos adverte ainda para a necessidade de, "sempre que se anotar uma oração, não se esquecer de anotar o ritual manual que a acompanha e seu simbolismo" (1993: 234). ${ }^{33}$ Seja no orar em voz baixa ou gritar, recitar ou cantar, é preciso estar atento para a gestualidade, os movimentos, o ritmo, as expressões obrigatórias que o acompanham..$^{34}$

32 Rubem Fernandes (1982) e José Carlos Pereira (2004) lembram ainda que os devotos das camadas populares encontram no sacrifício ritual dedicado aos santos um meio de mitigar os sofrimentos humanos e resgatar a esperança na vida.

33 Observação que lembra aquela de Benjamin (1994) ao final do magnífico "O narrador", quando fala da coordenação da alma, do olhar e da mão, típica do artesão. Afinal, a pergunta que se faz parece reforçar nossa hipótese da "gestualidade elementar da reciprocidade", na medida em que ele suspeita ser a relação entre o narrador e sua matéria - a vida humana ela própria - uma relação artesanal. Em outras palavras, também a relação entre corpo e dádiva é ela mesma uma relação performativa.

34 Ver o caso dos ritos orais funerários na Austrália, em que o canto feito ao morto representa um convite a um verdadeiro teatro. É bom que se diga que os sentimentos, embora expressem uma concepção subjetivada da individualidade, se inscrevem no plano sociológico da linguagem. Em outras palavras, para Mauss, "todas as expressões coletivas, simultâneas, de valor moral e de força obrigatória dos sentimentos do indivíduo e do grupo são mais do que simples manifestações, são sinais, expressões compreendidas, em suma, uma linguagem. Estes gritos, são como frases e palavras. É preciso [continua] 
Assim, nas folias, os gestos do silêncio, do canto melancólico, do fechar os olhos, do baixar a cabeça, colocar as mãos postas junto ao peito, fazer o sinal da cruz, estender as mãos em posição de graça, cada qual reforça o respeito, a subserviência, a relação do folião-devoto com o espiritual, com o sagrado. A reza e o canto promovem a mediação entre mundos supostamente separados. Enfim, inúmeros são os gestos que acompanham os ritos recitativos das orações e das rezas.

Reconhecendo no rito certo parentesco com a técnica e a magia, Mauss aproxima-se de uma perspectiva da ação simbólica em que os ritos se ligam "ao simples uso por uma série ininterrupta de fenômenos intermediários" (1981 [1909]: 265), ou seja, a matéria dos ritos encontra-se no cotidiano, no plano do mundo ordinário, contudo, a sua eficácia reside em poder transformar, ainda que temporariamente, a natureza das coisas, como faz a magia. Daí sua proximidade com a técnica e a magia. Para Mauss, a prece é "um rito religioso, oral, diretamente relacionado com as coisas sagradas" (1981 [1909]: 273). A prece é, então, um ato tradicional eficaz que pode causar fenômenos extraordinários; portanto, é como rito sagrado que se pode entender seu caráter mágico; ${ }^{35}$ afinal, "a prece é antes de tudo um meio de agir sobre os seres sagrados; estes é que são influenciados por ela, é nestes que ela suscita modificações" (1981 [1909]: 272). A prece não existe fora do ritual. Nesse sentido, a inscrição corporal envolvida na prece e nos rituais é que fornece as bases de uma "antropologia da performance" em Mauss. Nesta, a gestualidade simbólica performatizada através dos rituais de sacrifício e da prece leva Mauss a reconhecer nos ritos manuais uma forma de oração. Diz ele:

“... há certos ritos manuais, claramente simbólicos, que poderiam ser chamados orações, porque na realidade são uma espécie de linguagem por meio de gesto; por exemplo, todas as dramaturgias religiosas, que têm como finalidade reproduzir os altos feitos dos deuses, suas lutas contra os demônios, etc., são práticas equivalentes aos cânticos rezados que contam aos deuses sua própria história e os incitam a renovar suas façanhas" (1981 [1909]: 272).

De certa forma, é o que as folias de reis parecem dramatizar quando vivem por 13 dias a jornada bíblica dos três Reis Magos. Durante o rito natalino, um conjunto de gestos, técnicas, sentimentos, valores, comportamentos,

dizê-las, mas se é preciso dizê-las é porque todo o grupo as compreende. A pessoa, portanto, faz mais do que manifestar os seus sentimentos a outrem, visto que é mister manifestar-lhos. Ela os manifesta a si mesma exprimindo-os aos outros e por conta dos outros. Trata-se essencialmente de uma ação simbólica" (1981 [1921]: 332).

35 Tal afinidade pode ainda ser verificada a partir das considerações de Lévi-Strauss (1967) e de Malinowski (1976) sobre a natureza ritual oral da magia. 
enfim, performances verbais e corporais são "restaurados", tomando emprestado de Schechner (1988) sua definição de performance. Afinal, como reza o folião:

E chegou a hora sagrada de continuar a missão

Jesus, José e Maria [coro]

Diz a Escritura Sagrada que quando Jesus nasceu

Jesus, José e Maria

Numa parte do Oriente uma estrela apareceu

Jesus, José e Maria

Estrela nova que brilhava mais do que as outras, porém

Jesus, José e Maria

Caminhava caminhava para o lado de Belém

Jesus, José e Maria

Os três Reis do Oriente resolveram acompanhar

Jesus, José e Maria

E montaram em seus camelos e começaram a viajar

Jesus, José e Maria

Ouro, incenso e mirra levaram para ofertar

Jesus, José e Maria

Para chegar a Belém eles levaram 13 dias

Jesus, José e Maria

E por isso que fazemos semelhante romaria

Jesus, José e Maria

\section{CONCLUSÃO}

O corpo pensado como fenômeno social total adquire importância paradigmática na medida em que os gestos, as emoções, as técnicas, os cantos, as rezas, os sacrifícios, os prazeres, as brincadeiras, enfim, um sem-número de representações e expressões corporais, como gestos e emoções, nos deixam ver a profusão dos sentidos acionados nas jornadas dos Santos Reis. Assim, os gestos envolvidos no sistema da dádiva (dar, receber, retribuir, extensivos ao ofertar/pedir), expressam a lógica da reciprocidade com suas trocas simbólicas (e também políticas, econômicas, sociais, estéticas, morais, religiosas, etc.) realizadas, ora no plano da vida profana, ora no plano da vida sagrada, ora ainda promovendo a mistura entre ambas. A obrigação aliada à liberdade de dar, de receber, de retribuir, de ofertar/pedir/agradecer aos deuses e aos santos fazem destes gestos ou desta gestualidade mais do que um sistema de trocas interessadas, um complexo sistema de trocas simbólicas que tem nas gentilezas, amizades, favores, crenças, honrarias, graças espirituais, esperanças - dadas, recebidas, retribuídas, pedidas, oferecidas - um modo de produzir um sentido 
coerente para a vida e/ou uma ordem para o mundo, promovendo o diálogo entre os homens e seus santos.

A aproximação do sacrifício e da prece com o sistema de prestações totais da dádiva nos possibilita ampliar e aprofundar significativamente a formulação de uma teoria do ritual e a compreensão da performance como corporeidade. $\mathrm{O}$ estudo das folias nos permite, ainda, pensar a sociologia e a antropologia de Mauss de forma mais integrada, a exemplo do que ele mesmo defendeu como fato social total, ou seja, em Mauss também tudo se mistura: a dádiva com a prece, com o sacrifício, com a expressão obrigatória dos sentimentos, com a magia. ${ }^{36}$ Para ele pessoas e coisas, corpo, alma e sociedade se misturam. Do ponto de vista epistemológico, não é diferente com os objetos, teorias e métodos, respectivamente representados aqui em termos de folia de reis, trocas simbólicas e fato social total.

Em suma, os gestos de rezar, ofertar, brincar, saltar, dançar, etc. são a expressão performativa da corporeidade nas folias de reis. O corpo é fundamento; o corpo e seus gestos são fontes de sentido nas folias. A reza não é só uma manifestação de fé, é também uma performance corporal. Nas folias de reis, o gesto e o verbo formam um só corpo. E o corpo reza, sofre, brinca, salta, dança, cansa, chora... Nas folias de reis, a relação entre o corpo e a dádiva pede que se considere também o sacrifício e a prece, as expressões obrigatórias do sentimento e as técnicas do corpo.

36 Claude Lévi-Strauss (2003 [1950]) observa, em "Introdução à obra de Marcel Mauss", que o "Ensaio sobre a dádiva", de 1925, começa onde parou o "Esboço de uma teoria geral da magia", de 1903. 


\section{BIBLIOGRAFIA}

AUSTIN, John, 1990, Quando Dizer é Fazer: Palavras e Ação. Porto Alegre, Artes Médicas.

BAKHTIN, Mikhail, 1993, "Formas de tempo e de cronotopo no romance: ensaios de poética histórica”, em M. Bakhtin, Questões de Literatura e de Estética: A Teoria do Romance. São Paulo, Editora Unesp/Hucitec, 21 1-362 (3. ${ }^{\mathrm{a}}$ edição).

BENJAMIN, Walter, 1994, Obras Escolhidas: Magia e Técnica, Arte e Política. São Paulo, Brasiliense $\left(7 .^{\mathrm{a}}\right.$ edição).

BITTER, Daniel, 2008, "Versos de improvisos nas chulas dos palhaços de folias de reis", em Alexandre Pimentel e Joana Correa (orgs.), Na Ponta do Verso: Poesia de Improviso no Brasil. Rio de Janeiro, Associação Cultural Caburé, 104-107.

BITTER, Daniel, 2010, A Bandeira e a Máscara: A Circulação de Objetos Rituais nas Folias de Reis. Rio de Janeiro, 7 Letras.

BOURDieu, Pierre, 2006, "O camponês e seu corpo", Revista de Sociologia e Política, 26: 83-92.

BRANDÃO, Carlos Rodrigues, 1981, Sacerdotes da Viola: Rituais Religiosos do Catolicismo Popular em São Paulo e Minas Gerais. Petrópolis, Vozes.

BRANDÃO, Carlos Rodrigues, 1983, "Os mestres da folga e da folia”, em Áurea Sampaio et al. Estrutura e Processos Sociais de Reprodução do Saber Popular: Como o Povo Aprende?, vol. 2. Campinas, s/ed. disponível em < http://webcache.googleusercontent.com/search?q=cache:http://www.sitiodarosadosventos.com.br/livro/images/stories/anexos/mestres_que_me_ensinavam.pdf\&gws_rd=cr\&ei=IwcjWNl8yOxS_NKyWA > (última consulta em outubro de 2016).

CAILlÉ, Alain, 2002, Antropologia do Dom: O Terceiro Paradigma. Petrópolis, Vozes.

CASCUDO, Luís da Câmara, 1987, História dos Nossos Gestos. Belo Horizonte, Itatiaia.

CHAVES, Wagner, 2008, "Máscaras, performances e mímesis: práticas virtuais e significados dos palhaços de santos reis”, Textos Escolhidos de Cultura e Artes Populares, 5 (1): 75-88.

COUTINHO, Delzimar, e Marcus Antônio NOGUEIRA (orgs.), 2009, Folias de Reis Fluminenses: Peregrinos do Sagrado. Rio de Janeiro, Instituto Estadual do Patrimônio Cultural.

CSORDAS, Thomas, 1990, "Embodiment as a paradigm for anthropology", Ethos, 18 (1): 5-47.

DURAND, Gilbert, 1998, Campos do Imaginário. Lisboa, Instituto Piaget.

FERNANDES, Rubem César, 1982, Os Cavaleiros do Bom Jesus: Uma Introdução às Religiões Populares. São Paulo, Brasiliense.

GEERTZ, Clifford, 1989, A Interpretação das Culturas. Rio de Janeiro, Livros Técnicos e Científicos Editora.

GIRARD, René, 1990, A Violência e o Sagrado. São Paulo, Editora Unesp.

GODBOUT, Jacques, 1999, O Espírito da Dádiva. Rio de Janeiro, Editora Fundação Getúlio Vargas.

HAROCHE, Claudine, 1998, Da Palavra ao Gesto. Campinas, Papirus.

LABURTHE-TOLRA, Philippe, e Jean-Pierre WARNIER, 1997, Etnologia-Antropologia. Petrópolis, Vozes.

LE GOFF, Jacques, 1994, “Os gestos do Purgatório”, em J. Le Goff, O Imaginário Medieval. Lisboa, Estampa, 149-156.

LÉVI-STRAUSS, Claude, 1967, Antropologia Estrutural. Rio de Janeiro/Brasília, Tempo Brasileiro. 
LÉVI-STRAUSS, Claude, 2003 [1950], "Introdução à obra de Marcel Mauss", em M. Mauss, Sociologia e Antropologia. São Paulo, Cosac Naify, 1 1-46.

MALINOWSKI, Bronislaw, 1976, "O significado da linguagem nas sociedades primitivas", em C. K. Ogden e I.A. Richards, O Significado de Significado: Um Estudo da Influência da Linguagem sobre o Pensamento e sobre a Ciência do Simbolismo. Rio de Janeiro, Jorge Zahar Editor, 295-330 (2. ${ }^{\mathrm{a}}$ edição).

MARTINS, Paulo Henrique (org.), 2002, A Dádiva entre os Modernos: Discussão sobre os Fundamentos e as Regras do Social. Petrópolis, Vozes.

MAUSS, Marcel, 1981, Ensaios de Sociologia. São Paulo, Perspectiva.

MAUSS, Marcel, 1981 [1909], "A prece”, em Marcel Mauss, Ensaios de Sociologia. São Paulo, Perspectiva, 229-324.

MAUSS, Marcel, 1981 [1921], "A expressão obrigatória dos sentimentos (rituais orais funerários australianos)", em Marcel Mauss, Ensaios de Sociologia. São Paulo, Perspectiva, 325-335.

MAUSS, Marcel, 1993, Manual de Etnografia. Lisboa, Publicações Dom Quixote.

MAUSS, Marcel, 2003 [1904-1905], "Ensaio sobre as variações sazonais das sociedades esquimós: estudo de morfologia social”, em Marcel Mauss, Sociologia e Antropologia. São Paulo, Cosac Naify, 425-505.

MAUSS, Marcel, 2003 [1924], "Relações reais e práticas entre a psicologia e a sociologia", em Marcel Mauss, Sociologia e Antropologia. São Paulo, Cosac Naify, 315-344.

MAUSS, Marcel, 2003 [1925], "Ensaio sobre a dádiva: Forma e razão da troca nas sociedades arcaicas”, em Marcel Mauss, Sociologia e Antropologia. São Paulo, Cosac Naify, 183$-314$.

MAUSS, Marcel, 2003 [1934], "As técnicas do corpo", em Marcel Mauss, Sociologia e Antropologia. São Paulo, Cosac Naify, 399-422.

MAUSS, Marcel, 2003 [1938], "Uma categoria do espírito humano: a noção de pessoa, a de 'eu'”, em Marcel Mauss, Sociologia e Antropologia. São Paulo, Cosac Naify, 367-397.

MAUSS, Marcel, e Henri HUBERT, 1981 [1899], "Ensaio sobre a natureza e a função do sacrifício”, em Marcel Mauss, Ensaios de Sociologia. São Paulo, Perspectiva, 141-227.

MAUSS, Marcel, e Henri HUBERT, 2003 [1904], "Esboço de uma teoria geral da magia”, em Marcel Mauss, Sociologia e Antropologia. São Paulo, Cosac Naify, 47-181.

MERLEAU-PONTY, Maurice, 1992, O Visível e o Invisível. São Paulo, Perspectiva (3. a edição). PEREIRA, José Carlos, 2004, Sincretismo Religioso e Ritos Sacrificiais: Influência das Religióes Afro no Catolicismo Popular Brasileiro. São Paulo, Zouk.

RIVIÈRE, Jean-Loup, 1987, “Gesto", em Enciclopédia Einaudi 11: Oral-Escrito/Argumentação. Lisboa, Imprensa Nacional Casa da Moeda, 1 1-31.

ROCHA, Gilmar, 2011 , Mauss e a Educação. Belo Horizonte, Autêntica.

ROCHA, Gilmar, 2014, "A roupa animada: persona e performance na jornada dos Santos Reis", Cronos, 15 (2): 8-34.

RODRIGUES, Rogério, 1997, O Pensamento Antropológico de Marcel Mauss: Uma Leitura das Técnicas Corporais. Campinas, Universidade Estadual de Campinas, dissertação de mestrado em Educação.

SCHMITT, Jean-Claude, 1995, "A moral dos gestos”, em D. B. Sant'Anna (org.), Políticas do Corpo. São Paulo, Estação da Liberdade, 141-161.

SCHECHNER, Richard, 1988, “Victor Turner's last adventure”, em Victor Turner, Anthropology of Performance. Nova Iorque, PAJ Publications, 7-20. 
STEIN, Stanley, 1990, Vassouras: Um Município Brasileiro do Café (1850-1900). Rio de Janeiro, Nova Fronteira.

TRAJANO FILHO, Wilson, 2009, “Os cortejos das tabancas: dois modelos da ordem”, em M. L. Cavalcanti e J. R. Gonçalves (orgs.), As Festas e os Dias: Ritos e Sociabilidades Festivas. Rio de Janeiro, Contra Capa, 37-73.

TURNER, Victor, 1988, Anthropology of Performance. Nova Iorque, PAJ Publications.

TURner, Victor, 2008, Dramas, Campos e Metáforas: Ação Simbólica na Sociedade Humana.

Niterói, Editora da Universidade Federal Fluminense. 